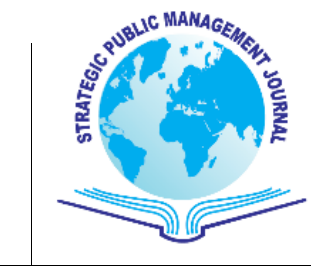

\title{
Kamu Kurumlarında Değişim Öncüsü: Dönüştürücü Lider
}

Strategic Public Management Journal Issue 9, pp.1/14 May 2019 DOI: $10.25069 /$ spmj.474706 Received:25/10/2018 Accepted:21/02/2019 (C) The Author(s) 2017 For reprints and permissions: http://dergipark.gov.tr/spmj

Seda Mumlu KARANFÍL ${ }^{1}$

Vala Lale TÜZÜNER ${ }^{2}$

$\ddot{O} z$

Günümüzde örgütlerin rekabet edebilmesi için değişim gereksinimi gün geçtikçe artmaktadır. Örgüt içerisinde değişim ihtiyacını ortaya koymak, çalışanların değişime uyumlarını sağlamak ve değişime karşı dirençlerini ortadan kaldırmak, onlarl motive etmek, mevcut gelecek firsatlarl öngörerek vizyon oluşturmak, gelecek koşullara örgütü ve çalışanlar hazırlamak, çalışanlar yeni fikirler üretme konusunda teşvik etmek dönüşü̈rücü liderlerin rolü olarak ele alınmaktadır. Özel sektör kadar Kamu'nun da değişime ayak uydurma ihtiyacı yadsınamaz bir gerçektir. Bu bağlamda çalışmanın temel amacı dönüştürücü liderlerin örgütsel değişim sürecindeki rollerini irdelemek ve bu rollere ilişkin çeşitli araştırma önermeleri geliştirmektir.

Türk ve Yabancı yazında yer alan Dönüştürücü Liderlik ve Örgütsel Değişim konulu akademik çalışmalar taranarak incelenmiş ancak liderlik ve değişim konulu çalışmaların kısıtlı olduğu görülmüştür. Bu doğrultuda Kamu alanında çalışan yöneticilerin dönüş̧ürücü liderlik özelliklerini kazanmastyla birlikte, kamu kurumlarında değişimin daha hızlı olacağı düşünülmüş ve bu düşünceden hareketle çalışma ortaya konmuştur. Kamu örgütlerinde çalışan yöneticilerin sadece liderlik özelliklerinin dönüşüm için yeterli olmadĭ̆l, dönüş̧ürücü liderlik özelliklerinin kazanılabileceği, çalışanların dönüşüme katılması ve fikirlerinin alınması, onlara değer verilmesi ile bu sürecin başarll bir şekilde gerçekleştirilebileceği vurgulanmak istenen noktadır. Değişimi kurumsallaştırma dönüşürü̈cü liderin başarısıyla gerçekleşmektedir.

Bu çalışmada J.P.Kotter'in Değiş̧imi yönetme başlıklı makalesinden yola çıkllarak, dönüş̧ürücü liderlerin süreç içerisindeki rolleri üzerine önermeler geliştirilmiştir.

Anahtar kelimeler: Dönüştürücü Liderlik, Örgütsel Değişim, Liderlik, Değişim, Kamuda Dönüştürücü Liderlik.

\footnotetext{
${ }^{1}$ İstanbul Üniversitesi, İşletme Fakültesi, İnsan Kaynakları Yönetimi Anabilim Dalı, sedamumlu@ gmail.com

${ }^{2}$ Prof.Dr., İstanbul Üniversitesi, İşletme Fakültesi, İnsan Kaynakları Yönetimi Anabilim Dalı, 1tuzun@istanbul.edu.tr
} 


\section{Abstract}

Nowadays, the need for change for the organizations to compete is increasing day after day. It is the role of transformational leaders to demonstrate the need for change within the organization, to assure the adaptation of employees to the change and to eliminate the resistance to the change, to motivate them, to create a vision by foreseeing the future opportunities, to prepare the organization and employees to the future conditions, to encourage the employees to produce new ideas. The need to adapt the private sector as well as the public sector to the change is an undeniable fact. Our main objective in this context is to examine the role of transformational leaders in the process of organizational change and to develop various research propositions, related to these roles.

The academic studies on Transformational Leadership and Organizational Change taking part in Turkish and Foreign Literature have been scanned further to the research. The studies have been examined but it has been observed that the studies on leadership and change are limited. It was thought that this research will contribute even a little to the literature.

With this study, proposals have been developed on the roles of transforming leaders within the process, through John. P Kotter's article "The 8 Step Process for Leading Change”. The point highlighted is that the leadership characteristics of the managers working in public institutions are not enough for the change, that the transformational leadership characteristics can be gained, that the process can be achieved successfully with the participation of employees in the change and to take their point of view and to appreciate them. Institutionalization of the change is realized with the transformational leader's success.

Key words: Transformational Leadership, Leadership, Organizational Change, Change, Public Transformational Leadership.

\section{GİRIŞ}

Günümüzde örgütlerin rekabet edebilmesi için değişime olan ihtiyaçları gün geçtikçe artmaktadır. Örgüt içerisinde değişim ihtiyacını ortaya koymak, çalışanların değişime uyumlarını sağlamak ve değişime karşı dirençlerini ortadan kaldırmak, onları motive etmek, mevcut gelecek firsatları öngörerek vizyon oluşturmak, gelecek koşullara örgütü ve çalışanları hazırlamak, çalışanları yeni fikirler üretme konusunda teşvik etmek dönüştürücü liderlerin rolüdür. Bu bağlamda teknolojinin ve hızlı değişimin yaşandığ günümüz 21. yüzyıl işletmelerinde dönüştürücü liderlik kavramı giderek önem kazanmaktadır. Özel sektör kadar Kamu'nun da değişime ayak uydurma ihtiyacı yadsınamaz bir gerçektir.

$\mathrm{Bu}$ bağlamda araştırmanın amacı Kamu kurumlarındaki liderlerin dönüştürücü liderlik özelliklerinin ve örgütsel değişim sürecindeki rollerinin incelenmesi ve bu konu ile ilgili çeşitli araştırma önermelerinin geliştirilmesidir. Bahsedilen amaç doğrultusunda öncelikle örgütsel değişim kavramı, dönüştürücü liderlik ve etkileşimci liderlik kavramları tanımlanacak ve örgütsel değişim sürecinde etkili olan dönüştürücü liderlik rollerinden bahsedilecektir.

\section{1. ÖRGÜTSEL DEĞIŞiM VE KAMU YÖNETIMIINDE DEĞIŞiM}

İşletmeler zamanla yaşanan sosyal, siyasal, kültürel ve teknolojik değişimlere ayak uydurmak zorunda kalmakta ve gittikçe karmaşıklaşan sorunlar karşısında yeni çözüm arayışlarına girmektedirler. Bu arayış ile gelişim sürekli devam etmektedir. Yaşam ve işletmeler için önemli bir kavram olan değişimin tanımını yapmak 
oldukça zordur (Kozak ve Güçlü, 2003: 1). Genel olarak değişim içinde bulunulan durumun mevcut koşullara göre daha da iyileştirilmesi, geliştirilmesidir.

Örgütsel değişim ise, Trahant ve Burke'ye göre örgütlerin amaçlarına ulaşmak için yaşanan değişimlere ayak uydurması durumudur. Örgütlerin yeni durumlara ayak uydurma, hızlı gelişmeleri yakalama, teknolojiden yararlanabilmeleri için değişimi takip etmeleri kaçınılmazdır (Güçlü ve Şehitoğlu, 2006).

Başarılı bir değişim iki aşamayı takip etmektedir. Birincisi dönüşüm diğeri ise işlemdir. Dönüşüm dış çevre hakkında bilgi sahibi olmanızı sağlar. Diğer taraftan çalışanların yönetim algısı nedir, çalışanlar firmanın kültürü hakkında ne düşünüyor? gibi soruların cevabı dönüşüm için bilgi sağlamaktadır. İkinci olarak ise işlemsel bakımdan, raporlama ve iş kolları organizasyon etkinliğini nasıl etkilemektedir. Firma takım çalışması ve özerkliğe destek veriyor mu? İşler ile ilgili politika, prosedür yada sistem hakkında ne düşünüyorlar. Çalışanların performans sorunları neler, çalışanların becerileri yaptıkları işe uygun mu? Şirket karlı mı, üretken mi? gibi sorulara verilen cevaplar organizasyonel değişiklik için yararlı olmaktadır. Alınan yanıtlar bir değişim çabası planlamaya ve başlatmaya olanak sağlamaktadır (Trahant ve Burke, 1997). Bu doğrultuda, çalışmanın bu kısmında, kamu yönetimi alanında yaşanan değişim ve dönüşüm Osmanlı'dan günümüze kadar ele alınmıştır.

Gelişmiş dünya ülkeleri teknoloji, çevre, ekonomi ve yönetim gibi alanlarda özellikle 20.yy.'in sonlarından itibaren farklı bir dönüşüm içine girmiştir. Değişimden etkilenen önemli bir olgu da devletlerin yönetim yapılarında gerçekleşmektektedir (Arslan,2010: 21). Türkiye'de benzer bir ivme ile çeşitli alanlarda dönüşüm içine girerek kamu yönetimi alanında değişim ile birlikte yenilenme yaşamaktadır. Türkiye'de çeşitli dönemlerde kamuda yeniden yapılanma çalışmaları gerçekleştirilmiş, ancak son yıllarda özellikle kamuda çalışan personele olan bakış açısının değişmesi ile birlikte daha kalıcı değişimler göze çarpmaktadır.

Ülkemiz Kamu Yönetiminin kökleri Osmanlı İmpartarluğu'na dayanmaktadır (Yılmazöz,2009: 293). Osmanlı döneminde gelişen yönetim sisteminin özelliklerini şöyle özetlemek mümkündür: Yönetim sistemi merkezi bir yapıda olup, kararlar merkezde alınmaktadır. Kurallar ve mevzuat yönetim sisteminin önemli yapıtaşları olup, bunlara sıkı bağlılık söz konusudur. Yönetim sisteminde gelenekçilik söz konusudur, bu durum değişime dirence sebep olmaktadır. Özellikle devlette çalışacak memurların seçiminde yönetim seçkinci bir politika izlemektedir. Bir diğer ifade ile memurların eğitimli olmasını ister ve devlet memurlarına değer verirlerdi (Canman, 1995: 249).

Kamu yönetimi, Osmanlı'dan gelen mutlakiyetçi bir anlayışa sahip iken Cumhuriyet yönetimine geçiş yapan Türkiye'de aşırı bir merkeziyetçilik hakim olup, bunun terk edilmesi zaman almıştır. Osmanlı yönetiminden miras kalan bu anlayış yumuşatılmış bir şekli ile hala kamu yönetiminde etkinliğini sürdürmektedir (Lamba, 2010: 153).

Dinçer ve Yılmaz "Değişimin Yönetimi için Yönetimde Değişim” başlıklı çalışmalarında kamuda yeniden yapılanlanma çalışmalarını üç evrede ele almaktadırlar. 1980'lere kadar "idari reform” olarak şekillenen dönemde örgüt yapısı, süreçleri ve prosedürleri iyileştirmeye yönelik çalışmalar yapılmış ve bu dönem ilk evre olarak adlandırılmaktadır. İkinci evre ise, 1980 yıllarda devletin rolünün yeniden tanımlanması ve işlevlerinin sınırlandırılması üzerinde durulan bir dönem olup özel sektör uygulamaları örnek alınarak kamu anlayışının yeniden şekillendiği bir dönem olarak tanımlanabilir. Üçüncü evre ise, 1990'lardan itibaren kamunun toplum ile düşünülmesi yaklaşımının önem kazandığı dönemdir. Sivil toplum örgütleri ve kamu yönetiminin toplum ile etkileşimi üzerine odaklanan "yönetişim” anlayışı bu döneme hakim olmuştur. Özetle, 1990'l1 yıllar, devletin her alanında reformlar yaşandığı ve yapının önemli ölçüde değiştiği bir dönem olarak ifade edilebilir (Dinçer ve Y1lmaz,2003:32). 
1990’l1 y1llardan itibaren birçok ülkede ve Türkiye'de kamuda verimliliği ve etkinliği arttırmak, halka yönelik hizmetleri iyileştirmek, harcamaları azaltmak, yöneticilerin sorumluluklarını geliştirmek amacı ile çeşitli çalışmalar yapılmıştır. Bu yenilenme çalışmaları kamu yöneticileri üzerinde bir baskı oluşturmuş ve kuruluşların daha verimli çalışmalarına yönelik özel sektörde yararlanılan yaklaşımları kullanarak değişimi gerçekleştirmeye çaba göstermişlerdir. Yönetim tarzlarının değişmesi, farklı bakış açılarının geliştirilmesi ile etkinlik ve etkililik konuları ön plana çıkmıştır (Yalçın, 2002: 103). Yönetim tarzlarının değişmesi ile birlikte, kamu yönetimi geleneksel yapılardan, daha katılımcı ve şeffaf bir yönetim yapısının hakim olduğu yeni yönetim yaklaşımlarını benimsemeye başlamıştır. Bu bağlamda yetkilendirme, yetki devri, kademe azaltma, ekip çalışması, süreç yenileme, yeniden yapılandırma, teknolojik gelişmelere uyum gibi çalışmaları içeren çağdaş bir yönetim anlayışı ortaya çıkmaktadır (Öztop, 2016:2).

Osmanlı döneminden bu yana kamu yönetimi değişim sürecini sürdürmekte, ancak geçmişin izleri halen bazı alanlarda göze çarpmaktadır. Yukarıda da ifade edildiği gibi kamu yönetimi alanında gerçekleşecek olan değişimin başarılı olmasında insan kaynağı önem arz etmekte ve insan kaynağının etkin, verimli olabilmesi için yönetim tarzlarının da güncellenmesi gereklilik olarak ortaya çıkmaktadır. Özellikle sözkonusu işgücünü yönetecek olan kişilerde liderlik özelliklerinin ve anlayışının olması kamudaki değişime ivme kazandıracaktır. Sonuç olarak günümüzde liderlik özelliklerinin kamu yöneticilerine kazandırılması ile birlikte yeni yönetim yaklaşımlarının uygulanabilirliğinin artması muhtemeldir.

\section{ETKILEȘIMCİ LIDERLIK}

Kamu ve özel sektör yöneticilerinin gittikçe dinamikleşen iş ortamında farklı roller üstlenmeleri beklenmektedir. Bu doğrultuda, yöneticilerin "yönetici" ve "lider" iki temel rolü ortaya çıkmakta ve farklı zamanlarda bu rolleri kullanmaları beklenmektedir. Koçel (2011) liderliği, belirli şartlar altında, belirli kişisel ve grup amaçlarını gerçekleştirmek üzere, bir kimsenin başkalarının faaliyetlerini etkilemesi ve yönlendirmesi süreci olarak tanımlamaktadır. Bir diğer ifade ile liderlik sürecinin temel yapıtaşı liderin kendisi olup, bağlı olduğu kuruma ve ekip üyelerine vizyon kazandıran kişi liderdir. Burns vd. (2006) liderliği, liderin takipçilerini motive ettiği, onların davranışlarını değiştirebildiği ve çalışanları ile karşılıklı ilişki kurabildiği bir süreç olarak tanımlamaktadır. Günümüzde liderlik, yeni yönetim yaklaşımları ile birlikte, değişerek yeni lider tipleri ortaya çıkmaktadır. Etkileşimci, dönüştürücü, karizmatik ve otantik liderlik gibi yeni lider türleri literatürde yerini almaktadır. Bu çalışmada ise, işe yönelik lider olarak da tanımlanan "etkileşimci lider" ve değişimi ve yenilikçiliği destekleyen lider olarak tanımlanan "dönüştürücü lider" kamu yönetimi bağlamında ele alınmıştır.

Lider ve grup üyeleri arasında koşullu bir ödül takas ilişkisinin varlığını savunan etkileşimci liderlik, işgörenlerin istenen performansı göstermesi ve bunun sonucunda neler elde edeceğini açılar (Korkmaz vd, 2012: 7). Bu yaklaşım lideri günlük görevlerin yerine getirilmesini, çalışanların performans göstermesini sağlayan kişi /yönetici olarak kabul edilmektedir (Morales ve Molero, 1995).

Bass'a (1985) göre, etkileşimci lider, örgütün elindeki kaynakları en yüksek verim ile kullanmak arzusundadır. $\mathrm{Bu}$ anlayış, işlerin sürekliliğinin sağlanması ve günlük iş aktivitelerinin yerine getirilmesi açısından yararlı görülebilir. Ancak personelin iş ile uyumunun tasarlanması, değişimin uygun zamanda gerçekleştirilmesi gibi noktalarda yeterince başarılı olamamaktadır. Bu sebeple etkileşimci lider değişime değil; işlerin önceden planlandığı gibi sürdürülmesine ve doğru olarak yapılmasına odaklanmış bir tarza sahiptir (Bass, 1985).

Etkileşimci liderlik akademik yazında dönüştürücü liderlik ile birlikte ele alınmaktadır. Venable ve Gardiner (1998)'e göre etkileşimci ve dönüştürücü liderliğin oluşturduğu kavramlar temelde birbirlerine benzerlik 
gösterse de, etkileşimci liderliğin, yönetimde duyulan ihtiyaçlar ve çevreye uyum sağlama konularında yetersiz kalması, dönüştürücü liderlik kavramının gelişmesine neden olmuştur.

\section{DÖNÜŞTÜRÜCÜ LİDERLIKK}

Dönüştürücü liderler karizma, ilham verme, entelektüel uyarım aracılığı ile izleyicilerini etkilemektedir. İzleyicinin olgunluk düzeyini, kendini gerçekleştirme ve başarısını arttırmaktadır. Lider gelecek planlarına nasıl ulaşılabileceği konusunda örnek teşkil eder, yüksek performansa ulaşmak için standartlar belirlerken ve güven oluştururken idealize edilmiş etki ve ilham verici liderlik sergiler. Takipçilerin yenilikçi ve yaratıcı olmaları için entelektüel uyarım sağlar. Takipçilerinin gelişim ihtiyaçlarını belirlemek, onları destelemek konusunda bireysel ilgi gösterir (Bass, 1999: 11). Burns vd. (2006) "liderlerin ve takipçilerinin birbirlerini daha yüksek ahlaki ve motivasyon seviyelerine yükselttikleri "bir süreç olarak tanımlamaktadır. Dönüştürücü liderler ahlaki değerlere (eşitlik, barış, insani yardım) hitap ederek takipçilerinin bilinç düzeyini yükseltmeye çalışır. Podsakoff vd. (1990) liderlerin geleceğe dair bir vizyon oluşturduğunu ve bu vizyona uygun ortak bakış açısı geliştirdiklerini ifade etmektedir. Oluşan vizyona uygun, grup hedeflerinin kabulünü teşvik eden, takipçilerine bireysel destek sağlayan ve bir model oluşturan liderler, temel değer, inanç ve tutumlarında takipçilerinin izleyebilmeleri için değişim gerçekleştirirler.

Avolio vd. (1997) dönüştürücü liderliğin idealize etki, ilham verici motivasyon, entelektüel uyarım ve bireysel ilgi olmak üzere dört boyuttan oluştuğunu ifade etmektedir. İdealize etki, dönüştürücü liderin vizyon belirlediği, zorlu hedefler oluşturduğu ve takipçilerini vizyon ve hedefler doğrultusunda teşvik ettiği boyuttur. $\mathrm{Bu}$ boyutta liderler takipçileri tarafindan beğenilen, saygı duyulan ve güvenilen bir rol modeli oluşturmaktadır. İdealleştirilmiş etki sağlayan liderler en iyi performans ve gelişimi başarmak için takipçilerinden ekstra çaba beklerler (Bass ve Avalio, 1992: 22). İlham verici motivasyon boyutu, takipçilerine ilham vererek organizasyonun vizyonuna bağlı kalmayı ifade eder. Takım üyelerinin hedeflere ulaşmaları için takım ruhunun oluşumuna katkı sağlar (Bass ve Riggio, 2006: 11-14). Avalio ve arkadaşlarına göre ilham verici liderler takipçilerinde iyimserlik ve coşku oluştururlar. Gelecek ile ilgili beklentilerini açıkca ifade eder ve onları bu doğrultuda desteklerler. Daha yüksek performans ve gelişim için gerekli enerjiyi uyarırlar. Üçüncü boyut ise entelektüel uyarımdır. Bu boyut liderin takipçilerini inovasyon ve yaratıcılık açısından uyarması ile ilgilidir. Liderler geçmiş problemleri çözmek için takipçilerini yeni çözüm yolları bulmaya teşvik eder, benzersiz ve yenilikçi bakış açısı ile sorunların üstesinden gelmeleri için onları geliştirirler. Son olarak ise bireysel ilgi boyutunda lider takipçilerinin yetenek ve ihtiyaçlarına odaklanır (Bass vd, 1992). Lider takipçilerinin başarı ve büyüme ihtiyaçlarına önem verir ve onlara bir koç, akıl hocası gibi davranır. (Bass vd, 2006). Dönüştürücü liderler, sahip oldukları özellikler ile değişimi başlatma, sürdürme ve sonuçlandırma da güçlükleri aşabilecek kişiler olarak tanımlanabilirler (Tüfekçi, 2008: 203-208).

\section{4. ÖRGÜTSEL DEĞiŞiMIM SÜRECINDE DÖNÜŞTÜRÜCÜ LIDERIN ROLÜ}

Kuruluşlar yapılarına uygun unsurları bir araya getirirler. Örgütlerin sektörüne, türüne göre farklı değişim ihtiyaçları sözkonusu olabilir. Altyapıları, iş sistemleri (performans yönetimi, idari işlemler, politikalar), bilgi teknolojisi ve uygulamaları, çalışanların bireysel yetenekleri bu değişimlere örnek olarak verilebilir (Recardo, 1995: 9). Son yıllarda işletmelerin değişime duydukları gereksinimi toplam kalite, kültürel değişim, değişim mühendisliği, yeniden yapılanma gibi yönetim uygulamalarından yararlanarak gerçekleştirmeye çalıştıkları görülmektedir. Bu değişim sürecinde temel amaçlardan biri de, sözkonusu değişimleri gerçekletirerecek yöneticileri geliştirmek, yönlendirmek ve çalışanlarını teşvik etmelerini sağlamaktır. Başarılı bir değişim süreci çeşitli evreleri içermekte ve bu evrelere sıkı sıkıya bağlılık, sürecin başarısında önemli bir etken olarak karşımıza çıkmaktadır (Kotter, 1995). Aşağıda değişimin başarısında etkili olan evreler açıklanmıştır. 


\section{1. İvedilik Duygusu Oluşturmak}

Değiş̧im sürecinde, ivedilik duygusu oluşturmak zorunludur. Çünkü bir değişimi başlatmak işbirliği gerektirmektedir. Çalışanlar motive edilmeden bir birlik sağlanmayacak, insanlar değişime yardımcı olmayacak ve çabalar karşılıksız kalacaktır. İlk sürecin başarısızlığı, liderlerin çalışanları konfor alanlarının dışına çıkarmanın güç olduğunu değerlendirmemelerinden kaynaklanmaktadır. Bazen ivedilik yaratma konusunda sabırları azalır ya da yöneticiler başarılarını fazla abartırlar. Çoğu zamanda işlerin kötüye gideceği ihtimali yöneticilerin düşünme ve odaklanma becerilerini azaltabilir. Yöneticiler çalışanların morallerinin bozulmasından, finansal problemlerin oluşmasından ve bundan dolayı suçlanmaktan ve olası tepkilerden çekinirler. Tüm tepkilere karşı bu değişime olan ihtiyacı savunabilecek liderlere ihtiyaç vardır. Bir diğer ifade ile, yeni bir sistem yaratmak güçlü liderlik istemektedir (Kotter, 1995). Bu noktada değişimin öncüsü olarak dönüştürücü liderler değişimi başlatma, değişime karşı oluşan direnci azaltma, değişimi sürdürme konularında önemli rol sahibidir. Bu evrede, etkileşimci ve dönüştürcü liderlik olguları ortaya çıkmaktadır. Etkileşimci liderin temel özellikleri arasında, günlük işlerin ve hizmetin daha kaliteli, satış rakamlarının daha yüksek olması, birim başına düşük maliyet sağlanması gibi konulara odaklanmak yer almaktadır. Yetkilerini astları ile paylaşmadıklarından güven ortamı oluşturmada zorluk çekebilmekte ve karşılıklı güvenin azalması da çalışanlar ile bilgi paylaşımını kısıtlamaktadır. $\mathrm{Bu}$ durum liderin örgütsel değişimi örgütlemesinde önemli engellerden biridir.

Uysal ve Öztop'un (2014) yılında kamu da yapmış oldukları araştırma bulgularına göre kamu çalışanlarının değişime direncinin en önemli bulgularından birincisi değişime ilişkin bilgi sahibi olmamaları ve ikinci sırada yönetime güvenmemeleri gelmektedir. Tengilimoğlu'nun (2005) kamu da yaptı̆̆ araştırmanın bulgularına göre kurumlardaki yöneticilerin astlarına zaman ayırmadıkları, onların ihtiyaçlarını algılama ve anlamada sıkıntı çektikleri, çalışanları motive edici faktörleri harekete geçiremedikleri ve karar alırken astlarını dinlemedikleri sonuçlarına ulaşılmıştır. Bass ve Steidlmeier'a (1999) göre etkileşimci liderler çalışanlarını motive etmekten ziyade başarı ya da başarısızlıkları doğrultusunda ödül veya ceza sistemi uygulamaktadırlar. Çalışanların örgüt içerisinde desteklenmesi, değişimden haberdar olması, liderleri ile pozitif ilişkiler içerisinde olması ve onlara güven duyması örgütün değişime direncinin azalması ve değişimin sürdürülmesine katkı sağlamaktadır. Bu doğrultuda aşağıdaki araştırma önermesi geliştirilmiştir.

Önerme1: Örgütsel değişime olan direnci kırma, değişimi başlatma ve sürdürme konularında kamu da çalışan dönüştürücü liderlerin etkileşimsel liderlere göre çalışanları daha fazla motive etmesi beklenmektedir.

\section{2. Güçlü Bir Rehberlik Ekibi Oluşturmak}

Kurumlarda değişim veya yenilenme faaliyetleri bazen bir veya iki kişinin çabaları veya düşünceleri ile başlamaktadır ancak zamanla bu süreçte farklı işbirlikleri gelişmektedir. Değişim veya yenilenme çabaları kurumun lideri tarafından desteklenmedikçe büyük bir değiş̧iklik beklenemez. Başarılı değişim sürecinde 1550 arası kişi biraraya gelerek, yüksek performans sağlama konusunda bağl1lık gösterirler. Bu ekip var olan hiyerarşinin dışında konunun uzmanlarının, müşteri temsilcilerinin ve güçlü bir sendika liderinin de içinde olabileceği bir gruptur. Bu kişileri bir araya getirecek, sorunları, firsatları değerlendirecek, güven içerisinde bir iletişim ortamı yaratacak lidere ihtiyaç duyulmaktadır (Kotter, 1995). Ekibe seçilen çalışanların diğerlerinden bilgi ve beceri olarak daha üstün ve güven duyulan kişiler olması da önemlidir. Dışarıdan gelen danışmanlar var ise süreci yönetmekten ziyade yönetenlere destek vermelidir (Kerman ve Öztop, 2014: 17-18). Takipçilerine destek olan, bireysel ve grup amaçlarını gerçekleştirmek, karşılaşılan zorlukları aşmak için fayda sağlayan liderler dönüştürücü liderlerdir. Bunun yanı sıra ahlaki ilkelere (disiplin, gelenek ve kurallara uyma) uygun davranır, çalışanların lidere ve organizasyona olan inancını, güvenini arttırmaya katkı sağlarlar. (Bass vd, 2006). Etkileşimci liderler ise Burns'e (1978) göre, örgütsel amaçlara ulaşma konusunda takipçilerini motive 
ederek yönlendirmektedir. Bu liderlik modelinde çalışanlar sadece rol ve görevleri belirlenerek hedeflenmiş amaçlar doğrultusunda yönlendirilir ve motive edilirler.

Dönüştürücü liderlerin grup üyelerini bir araya getirmesi, onları örgütün amaçları doğrultusunda harekete geçirmesi, etkileyebilmesi için kendine güvenmesi, kararlı davranışlar sergilemesi önemlidir. Bu bağlamda Gül ve Şahin (2011) tarafından yapılan araştırmada dönüştürücü liderlerin geleceğe yönelik risk alabilme, kendine güvenme, kararlı davranış gösterme bakımından kamuda bu liderlik özelliklerin mevcut olmadığı sonucuna ulaşmışlardır.

Walumbwa ve Lawler'e (2003) göre dönüştürücü liderlik grup odaklıdır. Bu sebeple bireysel kültürlerden ziyade toplulukçu kültürlerde çalışanların tutumları üzerinde olumlu etkiler yaratmaktadır. Çünkü toplulukçu kültürlerde bireyler bağlı oldukları gruplara güçlü bir aidiyet hissetmekte ve sadakat duymaktadırlar. Ayrıca değişim sürecinde çalışanların bir grup halinde ve bu grup ile uyumlu olmaları gerekmektedir. Wu vd. (2007) tarafından yapılan çalışmada grup uyum algısının artmasının liderlik özelliklerine de pozitif etki ettiği sonucuna ulaşılmıştır. Bass'a (1997) göre etkileşimci liderler ise gruplardan ziyade insan ve görevine birlikte odaklanmaktadır. Çalışanların gündelik işlerini, sorumluluklarını yerine getirmesi bu lider tarafından başarı olarak görülmektedir.

Önerme 2: Kamuda çalışan dönüştürücü liderlerin rehberlik ekibi oluşturma farkındalığının, etkileşimci liderlere göre daha yüksek olması beklenir.

\subsection{Vizyon Belirlemek, Vizyonu İletmek ve Çalışanlara Vizyona göre Hareket Yetkisi Vermek}

Başarılı bir dönüşüm sürecinde rehberlik ekibi, müşterilere, hisse sahiplerine ve çalışanlara çekici bir gelecek resmi çizmeye çalışır. Örgütün vizyonu, kurumun ulaşmak istediği yönü doğru bir biçimde açıklamalıdır. Vizyon mantıklı değilse, örgütü yanlış yöne ya da hiçbir yöne götürmeyecek karmaşık projelere dönüşebilir (Kotter, 2005). Örgütsel değişimin etkin bir şekilde yönetilmesi; örgütün mevcut durumunun anlaşılması, arzu duyulan geleceğin düşlenmesi, eylem planlarının hazırlanması ve bu yoldaki ilerlemeleri kapsamaktadır (Keçecioğlu, 2001).

Örgütsel değişim için gerekli unsurlardan birisi iletişim stratejisidir. Değişim sürecinde oluşturulan vizyon yazılı ve sözlü olarak çalışanlara duyurulur. Değişim teması ve vizyonu, zaman göstergeleri, değişimin sonucu, neyin değiştirilmesi gerektiğinin açık bir tanımı, değişimden kimlerin etkileneceği, organizasyonun ve çalışanların değişimden elde edeceği faydalar net olarak belirtilmelidir (Recardo, 1995). Vizyonun net bir şekilde ifade edilmesi, doğru iletişim kanallarının kullanılması, herkes tarafından aynı mesajın anlaşılması açısından önemlidir. Kotter (2005)'e göre çalışanların yüreklerini kazanmak güvenilir ve yoğun bir iletişim sürecinden geçmektedir. $\mathrm{Bu}$ süreçte çalışanlar faydalı bir değişikliğin olacağına inanmalıdır. Buna inanmadıkları sürece yeterli özveride bulunmayacaklardır. İyi iletişim kurabilen yönetici performans değerlendirmesinde personelin davranışlarının vizyona olan katkısından ya da olası sakıncalarından bahseder. Sıkıcı şirket yazışmalarını ilgi çekici hale dönüştürür. Geleneksel toplantıları heyecan verici hale getirir. Daha da ötesinde lider şirketin vizyonunu ve kültürünü canlı olarak taşır ve yaşatır.

Çalışanları ile etkili iletişim kurabilen liderler vizyonun gerçekleştirilebilmesi için çalışanlarını zihinsel olarak uyarır. Bununla birlikte onlara yeni amaçlar oluşturarak eski iş yapış biçimlerini gözden geçirmelerini sağlar ve onları gelişme ihtiyaçları açısından motive eder. Howell ve Avolio (1993)'de yaptıkları çalışmada dönüştürücü liderlerin yeni amaç ve yöntemler belirlemek suretiyle vizyon oluşturduklarını, etkileşimci liderlerin ise önceden tanımlanmış görevlerin yapılması ve problem çözme doğrultusunda çalışanlarını yönlendirdikleri sonucuna ulaşmıştır. Covey (1992) yaptığı araştırmada etkileşimci liderlerin günlük işlere odaklandığ1, dönüştürücü liderlerin ise günlük işlerin ötesinde plan ve hazırlık yaparak amaç ve vizyon 
oluşturdukları sonucuna varmıştır. Lider, gelişim ve değişim için çalışanlarına yön verme ve rehberlik etme süreçleri ile kendilerini yöneten takımların oluşmasına da katkı sağlayacaktır. Bu sayede örgütler gün geçtikçe kültürlerini değiştirerek takım çalışmasına dayalı dönüşüm gerçekleştirebileceklerdir (Eisenbach vd., 1999).

Örgütün yeni vizyon yönündeki değişimi kültürel açıdan da bir değişiklik yaşanmasını sağlayacaktır. Yeni kültürün rol ve davranış modellerinin şekillenmesi değişimin günlük işlere dahil edilmesi, iletişimin yukarı doğru geliştirilmesi, yapı, süreç ve uygulamalardaki değişiklikler ile gerçekleştirilir (Bass ve Avolio, 1993: 115). Yukarı doğru açık bir iletişimin kurulabilmesi ise güç mesafesinin dağılımına göre değişmektedir. Güç mesafesi bir kurum veya örgütte gücün eşit dağıtılıp dağıtılmama derecesi olarak ifade edilmektedir. Gücün eşit dağıtılması düşük güç mesafesi, gücün eşit dağıtılmaması yüksek güç mesafesi olarak tanımlanmaktadır (Hofstede- Soeters, 2002: 3). Hofstede'in (2000) yapmış olduğu araştırmanın sonucuna göre Türkiye yüksek güç mesafesi gösteren ülkeler arasında yer almaktadır. Türk kültüründeki yüksek güç mesafesi bireylerin otoriteyi kabul etmelerini ve karar alma süreçlerinde fikirlerini beyan etmelerini engellemektedir. Fikir beyan etme konusunda kişilerin korkup korkmamaları güç mesafesinin göstergelerinden biridir. Wasti (1998) yapmış olduğu araştırmada, fikirlerini üstlerine belirtme konusunda Türk çalışanların çekingen bir tavır sergilediğini ortaya koymuştur (Wasti, 1998:618).

Çalışanların fikirlerini açıkça beyan etmesi, değişime katılması liderin astları ile arasındaki güç mesafesine bağlıdır. Yaşanan kültürel değişimin kalıcı olması liderin değişimi sürdürmesi ile ilişkilidir. Değişimi sürdürmek ise insan kaynă̆ını iyi yönetebilmekten geçer. Aycan ve Kanungo (2000)'de yapmış oldukları çalışmada insan kaynaklarını iyi yönetebilmenin iç ve dış çevreyi anlamaktan geçtiğini ifade etmektedirler.

Organizasyonların değişim ile birlikte düşünen, hisseden, yaptığ 1 işin sorumluluğunu alan, kendisini işletmenin ortağı gibi gören astlara ihtiyacı artmaktadır (Tengilimoğlu, 2005: 12-14). Bu duyguları çalışanlarda harekete geçirmek ise onunla arkadaşça ilişkide bulunan, iletişimi kuvvetli bir lider tarafından gerçekleştirilmektedir. Çalışanlar yeni fikirler geliştirmek, yeni yaklaşımları benimsemek ve denemek için cesaretlendirilirler. Daha önce oluşturulan rehber ekip ile değişimi gerçekleştirecek kişilere eylem yetkisi verilir. Bu sayade çalışan yeni vizyonu anlayacak ve bunu gerçekleştirmeye istekli olacaktır. Bazı durumlarda değişimi gerçekleştirmek için engeller ortaya çıkar, engel bazen kişilerin kendisi bazen ise örgütlerdir (Kotter, 2005).

Örgütlerin değişimi engellemekten ziyade değişime öncülük etmesi gereklidir. Recardo (1995) da benzer şekilde üst yönetimin değişime öncülük etmesi gerektiğini söylemektedir. Organizasyonel değişimi sağlamak için üst yönetim astlarına değişimi gerçekleştirme yetkisi vererek personeli güçlendirmelidir. Globalleşme ve rekabet ortamında personel güçlendirme kavramı giderek önem kazanmaktadır. Güçlendirme kavramını incelediğimizde, çalışanların yardımlaşması, paylaşımda olması, yetiştirilmesi ve ekip çalışması yolu ile çalışanların karar verme yetki ve isteklerinin arttırılması ve geliştirilmesi süreci olarak tanımlanabilmektedir (Koçel,2011: 409). Lider personeli güçlendirmenin yanında onlara rol model olmalı ve değişime teşvik etmelidir. Gül ve Şahin'de (2011)'de yaptıkları çalışmada aynı şekilde liderin çalışanları teşvik etmesi ve desteklemesine değinmiştir Örgütte görevlerini en iyi şekilde yapacak şampiyonlar, onlara yardımcı olacak misyonerler olduğunda başarılı ve uzun vadeli değişimin gerçekleşmesi mümkündür. Bu özellikler ile dönüştürücü liderlikten bahsetmek mümkündür. Dönüştürücü liderler, takipçilerine yetki vererek onların asıl yapmaları gerekenden fazlasını yapmaları için cesaret verirler. Ancak Gül ve Şahin (2011) kamu da yapmış oldukları çalışmada dönüştürücü liderlik özelliklerine sahip liderlerin değişim yanlısı ve yenilikçi olmalarına karşın astlarını bu doğrultuda teşvik edemedikleri ve cesaretlendirmedikleri sonucuna ulaşmışlardır. Farklı araştırmalarda da kamuda liderlerin değişime öncülük etmek, vizyon oluşturmak gibi konularda vizyon sahibi olmadıkları, çalışanlara güven verme ve ilham olmaktan uzak bir tutum sergiledikleri sonuçlarına ulaşmışlardır. 
Her ne kadar kamu da liderler bu özelliklere sahip değilseler de bu özellikler eğitim ile geliştirilebilmektedir. Awamleh ve Gardner'ın (1999) yaptıkları çalışmada liderin vizyon oluşturma, vizyonu iletme, güven verme yeteneklerinin eğitim ile geliştirilebileceği sonucuna ulaşmışlardır.

Örgütsel değişim sürecinde vizyon oluşturmak, vizyonu iletmek, çalışanlar ile iyi iletişim kurmak, onları değişim yönünde harekete geçirerek yetki vermek önemlidir. Bazen sürecin belirsizliği, çalışanların olumsuz algıları, değişime yönelik endişeleri, kurumların kullandığı yöntem ve uygulamalar değişime karşı direnç oluşturmaktadır. Benzer bir sonuca Kerman ve Öztop (2014) tarafindan gerçekleştirilen çalışmada ulaşılmış, çalışanların kendi kurumlarındaki değişime tepkilerinin olumsuz olduğu ortaya çıkmıştır. Değişime direncin sebep olduğu belirsizlik, endişe, olumsuz algıların aksine değişim sürecini olumlu etkileyen uygulamalar da tespit edilmiştir (Kerman ve Öztop, 2014). Bunlar, çalışanların mevcut haklarının korunması, çalışanların değişim planları hazırlanırken görüşlerinin alınması, değişim başlamadan önce hedefler ve süreç hakkında çalışanlara bilgi verilmesi, sürece desteklerinin talep edilmesidir. Bu sonuç ile bağlantılı bir şekilde kamu da çalışanların maddi menfaat sağlamaktan daha çok fikirlerine değer verilmesini önemsediği ortaya çıkmaktadır.

Bu doğrultuda aşağıdaki araştırma önermeleri geliştirilmiştir:

Önerme 3: Güç mesafesinin yüksek olduğu Ülkemiz kamu kurumlarında dönüştürücü ve etkileşimci liderlerin vizyoner yaklaşımı daha az sergilemesi beklenmektedir.

Önerme 4: Kamu kurumlarında dönüştürücü liderlerin, etkileşimci liderlere göre çalışanları değişim konusunda daha fazla güçlendirmeleri beklenir.

\subsection{Kısa Vadeli Kazanımları Planlamak ve Oluşturmak, İyileştirmeyi Pekiştirmek, Daha Fazla Değişim Meydana Getirerek Yeni Yaklaşımları Kurumsallaştırmak}

Örgütlerde gerçek bir değişim, dönüşüm zamanla olmaktadır. Kısa vadeli amaçlar değişimin hız kazanmasına yardımcı olacak, ulaşılmaları ile de çalışanlar motive olacaklardır. Bu nedenle değişim sürecinde kısa vadeli hedeflerin oluşturulması önemli olup, sadece uzun vadeli hedeflere odaklanmak çok sayıda insanın değişime direnç göstermesine sebep olabilir. Başarılı bir dönüşüm gerçekleştirmede liderler performans iyileştirmelerinin, yıllık planlar için amaç belirlemenin, çalışanları destekleme ve maddi olarak ödüllendirmenin yollarını ararlar (Kotter, 2005). Değişim sürecinde çalışanların motive olması önemlidir. Çalışanların motive olması açısından da ödül sistemi önemlidir (Bass ve Avolio, 1993). Ödüllendirilen davranışlar yeni beceriler ortaya çıkarma, sürekli iyileşme, işbirliği oluşturma, takım çalışması ve öğrenmeye isteklilik sağlar (Recardo, 1995). Örgüt içerisinde başarılı birimlerin ödül alması Kerman ve Öztop (2014) tarafından yapılan araştırma sonucuna göre çalışanların değişime ilişkin algılarını olumlu yönde etkilemektedir. Yapılan araştırma sonuçlarına göre dönüştürücü liderler çalışanların yeni fikirlerini, değişime olan katkılarını, farklı iş yapış biçimlerini ödüllendirirken; etkileşimci liderler çalışandan beklenen performansı gerçekleştirmesi durumunda maddi veya manevi olarak ödül vermektedir. Diğer bir değiş ile etkileşimci lider günlük işlerin başarı ile yapılmasına odaklanmakta ve mevcut durum ile ilgilenilmesi değişimi destekleyen yeni fikirler ya da süreçlere karşılık aktif olmayan bir tutum sergilenmesine sebep olmaktadır. Bununla birlikte etkileşimci lider alt yap1 değişikliklerinin rutin performansı olumsuz etkileyebileceğini düşündüğünden, değişim veya yenilikleri takip ve uygulama fikrinden kaçınmaktadır (Bass, 1985).

Örgütsel değişimin gerçekleşmesini amaç belirlemek, çalışanların bu değişim sürecine katılmalarını sağlamak, yeni fikirleri, iş yapış biçimlerini ödüllendirerek onların motivasyonlarını arttırmak örgüt içerisinde değişime istekli takımların oluşmasına katkı sağladığı gibi örgütün gelişimi açısından da önemlidir. Örgütsel gelişim; örgütün bir bütün olarak performansının geliştirilmesidir (Koçel, 2003). Örgütsel gelişim bir değişim sürecidir ve bir bütün olarak örgütün ele alındığı, kültürel, yapısal ve süreçler arasında koordinasyonun 
düzenlendiği, örgütsel davranış konularında bilgi ve tekniklerin kullanıldığı örgütün etkinliğinin geliştirilmeye çalışıldığı faaliyetleri kapsamaktadır (Budak ve Budak, 2004). Örgütsel değişim meydana gelirken şirket bazı zorluklar ile karşılaşmaktadır. Bu süreçte liderler değişim sürecini engelleyen durumları ortaya koyar ve bu engelleri ortadan kaldırırlar (Recardo, 1995). Yine liderler işbirliği yaparak, uzmanlardan destek alarak ve politik taktikler kullanarak değişimi organize etmek gerçekleştirmek için akılcı çözüm yolları bularak verimlilik artışını sağlamaya çalışırlar. Bu bağlamda mevcut teknolojinin iyileştirilmesi, kaynakların en iyi şekilde kullanılması gibi konularda önemli kararlar verirler. Liderin bu aşamadaki çalışmaları aynı zamanda örgütün yapısını, teknolojisini, yönetim şeklini ve kültürünü etkileyecektir (Yukl, 1999: 288).

Liderin örgütsel değişim için gerçekleştirdiği çalışmalar şirketin kültüründe yer edinceye kadar kırılgandır ve doğru aksiyonlar alınmadığı takdirde gerileyebilmektedir. Bu nedenle vizyonun açık olmaması, ivedilik oranının yetersiz olması, rehber koalisyonun güçlü olmaması gibi konular değişimi olumsuz etkilese de kazanılan ivmeyi yok eden zaferin erken kutlanmasıdır. Başarılı liderler zafer ilan etmekten ziyade kısa dönemde kazanılan getirilerin kendilerinde yarattığı saygınlığg sorunları çözmede kullanır. Örneğin kimlerin terfi alacağı, işe alınacak kişilerin kimler olduğu gibi konulara önem verir ve değişim mühendisliği projelerine adım atarlar (Kotter, 2005).

Değişim, "bizim işleri yapış tarzımız budur” dendiğinde, şirketin kan dolaşımına sızdığında örgüt içerisinde yerleşmiş demektir. Değişimi şirketin kültüründe kurumsallaştırmada iki önemli etken vardır. İlk etken; yeni yaklaşımın, performansı arttırmaya nasıl yardımcı olduğunu göstermektir (Kotter, 2005). İkinci etken ise değişimi sürdürecek kuşağın yeni yaklaşımı temsil edecek nitelikte olmasıdır. Değişim organizasyonda insanlar ile gerçekleşecektir (Wiley, 2005). Bunun için gerekli zaman harcanmalı, gelecek için terfi koşulları değişmelidir aksi halde değişimin uzun sürmesi beklenmemelidir (Kotter, 2005).

Değişimin uzun soluklu olması ve en önemli değişim aracının insan olması bakımından örgütlerde insan sermayesi önemli bir kavramdır. İnsan sermayesini arttırmada insan kaynakları uygulamaları ve liderliğin etkisi büyüktür. Zhu vd. ( 2005) İnsan Kaynakları Yönetiminin ve liderlerin insan sermayesini arttırmada ve örgütsel sonuçlar üzerinde güçlü bir etkisinin olduğunu tespit etmişlerdir. Yapılan araştırmada dönüştürücü liderlerin karizma, ilham verici motivasyon gibi özelliklerinin yanı sıra insan sermayesini arttırma ve insan kaynakları uygulamalarını hayata geçirme olasılıklarının yüksek olduğu sonucuna varılmıştır. Bunun aksine etkileşimci lider ise iki farklı yönetim anlayışını benimsemektedir. Birinci yönetim anlayışında amaç, örgüt içinde oluşabilecek hatalara işlem sürecinde müdahele etmek ve hedeflerin planlandığı gibi sürdürülmesini ve bitirilmesini sağlamak ve çalışanları bu doğrultuda yönlendirmektir. İkinci yönetim anlayışında ise amaç gözle görülen bir problem yaşanmadıkça çalışanlara müdahale etmemek şeklindedir. Çalışanların problemleri çözemediği veya hata olan durumlara çalışanlara müdahale etmektedir (Howell ve Avolio, 1993: 891-902). Ayrıca sürekli ve kısa sürekli planlar için örgütün insan kaynağının en yüksek verim ile kullanmasını faydalı olarak görür. Bu sebeple doğası gereği değişim tasarlamak, personeli değişim yönünde teşvik etmek, değişimi zaman içinde uygulamak gibi konularda pek verimli değildir. Değişim ve yenilikçiliğin aksine işlerin doğru tamamlanmasına odaklanmış uygulama kapasitesindedir (Bass, 1985).

Önerme 5: Kamuda yeni fikirler üretmeye, değişime ve öğrenmeye istekli çalışanların var olmasını sağlayarak daha fazla değişimi etkileşimci liderden çok dönüştürücü liderlerin meydana getirmesi beklenmektedir. 


\section{SONUÇ}

Özel sektörde yaşanan değişim günümüzde kamu kurumlarında da gerekli hale gelmiştir. Çevrede yaşanan değişimler kurumları yeni yönetim modelleri ve anlayışları bulmaya itmektedir. Geleceğe yönelik ortaya çıkan ve beklenmeyen problemler hizmet kalitesini düşürebilmekte, maliyetleri yükseltmektedir. Dolayısıyla gelecek için orta, uzun vadeli planlar yapmak, vizyoner ve problemlere yeni bir bakış açısı ile çözüm üretmek önem taşımaktadır. Bu bağlamda kamu kurumlarında da dönüştürücü liderlere ihtiyaç gün geçtikçe artmaktadır.

Çalışmanın amacı kamu örgütlerinde dönüştürücü lider ve etkileşimci lider arasındaki farkı ortaya koyarak dönüştürücü liderlere olan ihtiyacın arttığı günümüzde bu liderlik özelliklerinin kurumlara sağladığı katkıları ortaya koymaktır. Çalışma kapsamında John P. Kotter tarafından geliştirilen örgütsel değişimin 8 adımı incelenmiş ve bu incelemede dönüştürücü lider ve etkileşimci lider karşılaştırılması yapılmıştır.

Yapılan araştırma sonucunda Türk ve Yabancı yazında yer alan Dönüştürücü Liderlik ve Örgütsel Değişim, Etkileşimci Liderlik konulu akademik çalışmalar taranmıştır. İncelemeler sonucunda, dönüştürücü liderlerin etkileşimci lidere kıyasla örgütsel değişime olan katkısı üzerine araştırma önermeleri geliştirilmiştir. Kamu kurumlarındaki liderlerin örgütsel değişimi başlatma, sürdürme ve kurumsallaştırmalarında önemli olan konular tespit edilmiştir. Dönüştürücü liderlerin çalışanlarına değişimden olumsuz etkilenmeyecekleri konusunda güven vermesi, değişim vizyonunu iletmesi, iyi iletişim kurması, onları cesaretlendirmesi, yetkilendirmesi, görüşlerini alması, başarıyı ödüllendirmesi gibi davranışlarının değiş̧im sürecine pozitif katkısı ile birlikte değişimin önündeki çalışan direncini kıracağı ileri sürülmüştür. Örgütsel değişimi kurumsallaştırmak açısından, çalışan davranışlarının ve iş yapış biçimlerinin değiştirilmesi önemli etkenler olarak görülmektedir. Bu bağlamda liderin kurumsallaşma üzerinde etkisi olduğu sonucuna varılmıştır.

Başarılı bir örgütsel değişimin gerçekleştirilmesi için amaç ve vizyon oluşturma, değişimi başlatma açısından önemlidir. Bu değişimin gerçekleştirilebilmesi için çalışanların değişimden haberdar olması, değişimin kendilerine ve şirketlerine faydası hakkında bilgi sahibi olmaları örgütün başarı için önemlidir. Lider çalışanlarının değişimden nasıl etkileneceğini, onlara nasıl fayda sağlayacağını, bu süreçten zarar görmeyeceklerini ve şirket için de kendileri içinde bu sürecin faydalı olacağını doğru iletişim kurarak aktarmalıdır. Bu bağlamda çalışmamız kapsamında da incelediğimiz dönüştürücü lider vizyon oluşturma, değişimi başlatma, çalışanları bu değişim sürecinde motive etme ve onların değişime direncini kırma konularında etkileşimci lidere göre daha başarılıdır. Çünkü etkileşimci lider günlük işlerin yapılmasına odaklanmakta, çalışanların çözemeyeceği sorunlara müdahale ettiğinden, kendisi değişim odaklı değil görev odaklı çalışmaktadır. Bu da çalışanlarda daha çok rutin iş yapma şekillerinin devam etmesi dolayısıyla farklı iş yapma biçimlerinin ortaya çıkmasını engellemektedir. Örgütün başarılı olabilmesi, performansının artması yeni fikirlerin oluşmasına, değişime istekli çalışanların varlığına, liderin değişim konusunda ki tutumuna, vizyon oluşturma yeteneği ile birlikte takipçilerini etkileme, onlara ilham olma konusundaki başarısına bağlıdır. Üst yönetimin değişime öncülük etmesi onlara değişimi gerçekleştirme konusunda yetki vermesi de önemli bir konudur. Bu bağlamda dönüştürücü liderler vizyon oluşturarak çalışanlarını harekete geçirebilen, onlara ilham ve rol model olan, değişim için çalışanlarına yetki veren bir liderlik yaklaşımıdır. Farklı iş yapış biçimlerini destekler ve ödüllendirir. Bunun aksine etkileşimci lider ise görev odaklı olduğundan günlük görevlerin gerçekleştirilmesi konusunda rol bilincine sahiptir, çalışanlarına yetki vermek yerine onları örgütsel amaçlar için motive eder ve bu doğrultuda çalışanlarını ödüllendirir.

Örgütsel değişim, örgütün gelişimini desteklerken aynı zamanda örgütün bir bütün olarak performansının iyileştirilmesine katkı sağlar. Lider bu gelişim sürecinde örgütü bir bütün olarak ele alır ve kültürel, yapısal, süreç bazında düzenlemeler yapar, örgütsel davranış konularında örgütün etkinliğini geliştirmeye çalışır. 
Teknolojik gelişmeleri takip eder, gerektiğinde uzmanlardan yardım alır, kaynakları en iyi nasıl kullanacağına karar verir. Tüm bu çalışmalar mutlaka örgütün kültüründe de bir takım değişimler gerçekleştirilmesine katkı sağlayacaktır. Önemli olan örgütün kültüründe gerçekleşen bu değişimin kalıcı olmasını sağlamak, çalışanların bu konudaki desteğini almak ve insan sermayesini iyi yönetmektir. İnsan sermayesi kurumlar için en önemli kaynaklardan biridir. Bu kaynağı iyi yönetebilmek için liderin kendini geliştirmesi, insan sermayesini arttırmada etkili olan insan kaynakları uygulamaları konusunda bilgi sahibi olması önemlidir. Bu bağlamda bahsettiğimiz iki liderlik yaklaşımından dönüştürücü liderin yapılan araştırma sonuçlarına göre insan kaynakları uygulamalarını hayata geçirme olasılığının etkileşimci lidere göre daha fazla olduğu sonucuna ulaşılmıştır. Çünkü etkileşimci liderin yönetim biçimi hedeflerin planlandığ1 gibi sürdürülmesine ve bitirilmesine aynı zamanda problemin ortaya çıkmasında ya da hata olan durumlarda müdahale etme şeklindedir.

$\mathrm{Bu}$ çalışamada etkileşimci lider ve dönüştürücü liderlik karşılaştırılmış, kamu kurumlarında örgütsel değişimi gerçekleştirme konusunda aşağıdaki araştırma önermeleri geliştirilmiştir:

Önerme1: Örgütsel değişime olan direnci kırma, değişimi başlatma ve sürdürme konularında kamu da çalışan dönüştürücü liderlerin etkileşimsel liderlere göre çalışanları daha fazla motive etmesi beklenmektedir.

Önerme 2: Kamuda çalışan dönüştürücü liderlerin rehberlik ekibi oluşturma farkındalığının, etkileşimci liderlere göre daha yüksek olması beklenir.

Önerme 3: Güç mesafesinin yüksek olduğu Ülkemiz kamu kurumlarında dönüştürücü ve etkileşimci liderlerin vizyoner yaklaşımı daha az sergilemesi beklenmektedir.

Önerme 4: Kamu kurumlarında dönüştürücü liderlerin, etkileşimci liderlere göre çalışanları değişim konusunda daha fazla güçlendirmeleri beklenmektedir.

Önerme 5: Kamuda yeni fikirler üretmeye, değişime ve öğrenmeye istekli çalışanların var olmasını sağlayarak daha fazla değişimi etkileşimci liderden çok dönüştürücü liderlerin meydana getirmesi beklenmektedir.

Kamu örgütlerinde çalışan yöneticilerin sadece etkileşimci liderlik özelliklerinin dönüşüm için yeterli olmadığı, dönüştürücü liderlik özelliklerinin de kazanılabileceği, çalışanların dönüşüme katılması ve fikirlerinin alınması, onlara değer verilmesi ile bu sürecin başarılı bir şekilde gerçekleştirilebileceği vurgulanmak istenmiştir. Çalışmada geliştirilen önermelerin ileri de nicel olarak araştırılması dönüştürücü liderlerin örgütsel değişim sürecine olan katkısı hakkında önemli bilgiler sağlaması beklenmektedir. 


\section{KAYNAKÇA}

Arslan, N. T. (2010). “Klasik-Neo Klasik Dönüşüm Süreci: Yeni Kamu Yönetimi”, CÜ İktisadi Ve İdari Bilimler Dergisi, 11(2), 21-38.

Avolio, B. J.,Bass, B. M. ve Jung, D. I. (1999), "Re Examining the Components of Transformational and Transactional Leadership Using the Multifactor Leadership Questionnaire", Journal of Occupational \& Organizational Psychology, 72(4): 441-462.

Awamleh, R., \& Gardner, W. L. (1999), "Perceptions of Leader Charisma and Effectiveness: The Effects of Vision Content, Delivery, and Organizational Performance”, The Leadership Quarterly, 10, 345-373.

Bass, B. M. (1999), “Two Decades Of Research And Development İn Transformational Leadership”, European Journal Of Work And Organizational Psychology, 8(1), ss. 11

Bass, B. M., \& Avolio, B. J. (1990), “ Developing Transformational Leadership: 1992 And Beyond”, Journal Of European İndustrial Training, 14(5), ss. 22.

Bass, B. M., \& Avolio, B. J. (1993), “Transformational Leadership And Organizational Culture”, Public Administration Quarterly, ss. 115.

Bass, B. M., \& Riggio, R. E. (2006), Transformational Leadership, Psychology Pres, ss. 11-14.

Bass, B.M. (1985), “Leadership And Performance Beyond Expectations”, New York: Free Press.

Bennis, W. ve Nanus, B. (1985), “Leaders”, New York: Harper and Row.

Başbakanlık, T. C. (2003). "Değişimin Yönetimi İçin Yönetimde Değişim”, The Change İn The Governance For The Governing The Change). Ankara: TC Basbakanlik.

Bommer, W. H., Rich, G. A., \& Rubin, R. S. (2005), "Changing Attitudes About Change: Longitudinal Effects Of Transformational Leader Behavior On Employee Cynicism About Organizational Change Journal Of Organizational Behavior: The International Journal Of Industrial", Occupational And Organizational Psychology And Behavior, 26(7), 733-753.

Canman, D. (1995), “Çağdaş Personel Yönetimi”, TODAİE Yayını 260, Ankara.

Covey, S. (1992). "Principle Centered Leadership". New York: Simon and Schuster.

Çetin, Ş. Korkmaz, M. ve Çakmakçı, C. (2012), "Dönüşümsel ve Etkileşimsel Liderlik ile Lider-Üye Etkileşiminin Öğretmenlerin Örgütsel Vatandaşlık Davranışı Üzerindeki Etkisi. Kuram ve Uygulamada Eğitim Yönetimi”, 18(1): 7- 36.7

Dinçer, Ömer, and Cevdet Yılmaz.(2003), "Kamu Yönetiminde Yeniden Yapılanma 1: Değişimin Yönetimi İçin Yönetimde Değişim”, TC Başbakanlık. ss. 32.

Hasan, G., \& Şahin, K. (2011), "Bilgi Toplumunda Yeni Bir Liderlik Yaklaşımı Olarak Transformasyonel Liderlik Ve Kamu Çalışanlarının Transformasyonel Liderlik Algısı”, Selçuk Üniversitesi Sosyal Bilimler Enstitüsü Dergisi, (25), ss. 245-246.

Hofstede, G. Ve Soeters, J. (2002), "Consensus Societies With Their Own Character: National Cultures İn Japan And The Netherlands," Comparative Sociology, 1(1): 1-17

Howell, J. M., \& Avolio, B. J. (1993), “Transformational leadership, transactional leadership, locus of control and support for innovation : key predictors of consolidated-business-unit performance", Journal of Applied Psychology, 78, 891-902.

Kerman, U., \& Öztop, S. (2014), "Kamu Çalışanlarının Örgütsel Değişim Direncini Etkileyen UygulamalarPractices To Affect Public Employees' Resistance To Organizational Change", Mehmet Akif Ersoy Üniversitesi Sosyal Bilimler Enstitüsü Dergisi, 6(10), ss. 17-18. 
Kerman, U., \& Öztop, S. (2014), "Örgütsel Değişim Sürecinde Kamu Çalışanlarının Algısını Etkileyen Uygulamalar”, Süleyman Demirel Üniversitesi İktisadi Ve İdari Bilimler Fakültesi Dergisi, 19(2), ss. 30-34.

Koçel, T. (2011), “İ̧̧letme Yöneticiliği”, (13.baskı), İstanbul: Beta Basım Yayım Dağıtım A.Ş.

Kotter, J. P. (1999), “Değişim”,(Çev.) Meral Tüzel Koçel, İstanbul: Mess Yayınları, 11-27

Kozak, M. A., \& Güçlü, H. (2003), "Turizm İşletmelerinde Değişim Yönetimi Üzerine Kavramsal Bir İnceleme" Isguc The Journal Of Industrial Relations And Human Resources, 5(1), ss. 1.

Lamba, M. (2010), “Osmanlı’dan Günümüze Türk Kamu Yönetimde Merkeziyetçilik-Adem-i Merkeziyetçilik Üzerine Bir İnceleme” Süleyman Demirel Üniversitesi Vizyoner Dergisi, 2(1), 131-156.

Masood, S. A., Dani, S. S., Burns, N. D., \& Backhouse, C. J. (2006), “Transformational Leadership And Organizational Culture: The Situational Strength Perspective. Proceedings Of The Institution Of Mechanical Engineers", Part B: Journal Of Engineering Manufacture, 220(6), ss. 942.

Morales, J.. F. ve Molero, F. (1995), “ Leadership İn Two Types Of Healthcare Organization”, In J.M. Peiro.

Öztop vd.(2018), “Kamu Yönetimi Reformaları, Türkiye Ekonomisinin Dönüşümü 2000'li Yıllarda Türkiye Ekonomisi" Umuttepe Yayın No: 179, İşletme-Ekonomi Dizisi: 72, ss. 8.

Podsakoff, P. M., Mackenzie, S. B., \& Bommer, W. H. (1996), “Transformational Leader Behaviors And Substitutes For Leadership As Determinants Of Employee Satisfaction, Commitment, Trust, And Organizational Citizenship Behaviors", Journal Of Management, 22(2), 259-298.

Recardo, R. J. (1995), “Overcoming Resistance To Change”, National Productivity Review, 14(2), ss. 9.

Saylı, H., \& Tüfekçi, A.( 2008), "Başarılı Bir Örgütsel Değişimin Gerçekleştirilmesinde Dönüştürücü Liderliğin Rolü”, Erciyes Üniversitesi İktisadi Ve İdari Bilimler Fakültesi Dergisi, (30), 193-210, ss. 203-208.

Şerif, Ş. M., \& Akın, H. B. (2003), “Teknoloji Yönetimi Ve Örgütsel Değişim”, Çizgi Kitapevi, Konya.

Tengilimoğlu, D. (2005), “Kamu Ve Özel Sektör Örgütlerinde Liderlik Davranışı Özelliklerinin Belirlenmesine Yönelik Bir Alan Çalışması”, Elektronik Sosyal Bilimler Dergisi, 14(14), ss. 12- 14

Trahant, B., Burke, W. W., \& Koonce, R. (1997), “12 Principles Of Organizational Transformation”, Management Review, 86(8), 17.

Venable, W. ve Gardiner, J. J. (1988), "Synergistic governance, leadership teams, and the academic

department head", Paper presented at the Annual Meeting of the Association for the Study of

Higher Education, St. Louis, Missouri.

Wasti, Syeda Arzu (1998), "Cultural Barriers In The Transferability Of Japanese And American Human Resources Practices to Developing Countries: The Turkish Case", The International Journal Of Human Resource Management, 9, (4): 608-631

Wu, C., Neubert, M. J., \& Yi, X. (2007), “Transformational Leadership, Cohesion Perceptions, And Employee Cynicism About Organizational Change: The Mediating Role Of Justice Perceptions", The Journal Of Applied Behavioral Science, 43(3), ss. 346.

Yalçın, A. (2002). “Değişim Yönetimi”, Nobel Kitabevi.

Y1lmazöz, M. (2009). “Türkiye’de Kamu Personel Yönetimi Sorunu”, Maliye Dergisi, 157, 293-302.

Yukl, G. (1999), “An Evaluation Of Conceptual Weaknesses İn Transformational And Charismatic Leadership Theories", The Leadership Quarterly, 10(2), 285-305.

Zhu, W., Chew, I. K., \& Spangler, W. D. (2005), "Ceo Transformational Leadership And Organizational Outcomes: The Mediating Role Of Human-Capital-Enhancing Human Resource Management", The Leadership Quarterly, 16(1), ss. 40. 